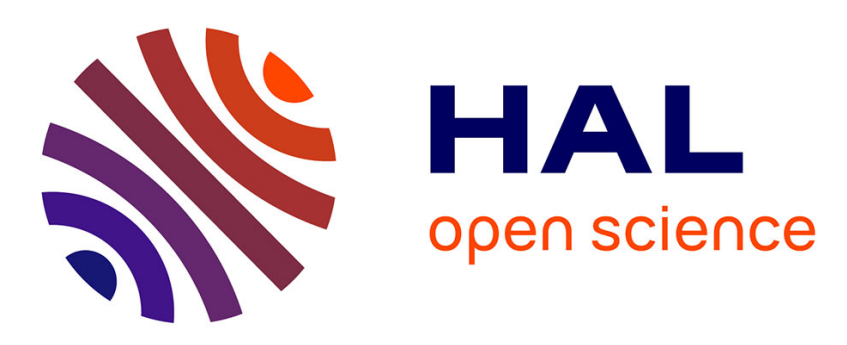

\title{
Association Française de Linguistique Appliquée (AFLA).
}

Grégory Miras, Alex Boulton, Natalie Kübler, Jean-Paul Narcy-Combes

\section{To cite this version:}

Grégory Miras, Alex Boulton, Natalie Kübler, Jean-Paul Narcy-Combes. Association Française de Linguistique Appliquée (AFLA).. European Journal of Applied Linguistics. , 2018, 6 (2), pp.315-326. 10.1515/eujal-2018-0004 . hal-01850695

\section{HAL Id: hal-01850695 https://hal.science/hal-01850695}

Submitted on 7 Feb 2020

HAL is a multi-disciplinary open access archive for the deposit and dissemination of scientific research documents, whether they are published or not. The documents may come from teaching and research institutions in France or abroad, or from public or private research centers.
L'archive ouverte pluridisciplinaire HAL, est destinée au dépôt et à la diffusion de documents scientifiques de niveau recherche, publiés ou non, émanant des établissements d'enseignement et de recherche français ou étrangers, des laboratoires publics ou privés. 


\section{Association Française de Linguistique Appliquée (AFLA)}

Grégory Miras*, Alex Boulton, Natalie Kübler, Jean-Paul Narcy-Combes

Abstract: This contribution to the European Journal of Applied Linguistics addresses the contextualized challenges that the Association Française de Linguistique Appliquée is still facing despite the fact that it was created as far back as 1964, at the same time as AILA. The landscape of French research may explain why the tag "Linguistique Appliquée" is not as widespread as its equivalents in some other scientific cultures.

Keywords: French, affiliate, AFLA, Linguistique appliquée

AFLA, the Association Française de Linguistique Appliquée is - like the other affiliates of the Association Internationale de Linguistique Appliquée (AILA) - a professional association for junior and senior researchers and practitioners working in the field of Applied Linguistics. However, AFLA has a particular historical status among all the other affiliates as it was created simultaneously with AILA in Nancy (France). Since then, AFLA has had to face a number of challenges, mostly due to this specific context and they explain its specificities nowadays.

\section{A brief history of AFLA ${ }^{1}$}

The Association Française de Linguistique Appliquée ${ }^{2}$ (AFLA) and The Association Internationale de Linguistique Appliquée ${ }^{3}$ (AILA) were both created in 1964 after the first international conference in Nancy (October 26-31 ${ }^{\text {st }}$ ) on "Semantic information in linguistics and in machine translation". The year 1964 is a keystone in Nancy (France) because many linguists were recruited creating a "euphoric atmosphere" (Carton 2015: 29) increased by numerous interdisciplinary connections. Moreover, it was the year when third-generation computers were released allowing more extensive data collection and analysis. AFLA was officially created on $21^{\text {st }}$ December 1964 by Guy Capelle as a non-profit association under the French law of 1901 (Figure 1). AFLA was probably created a month earlier as it is mentioned that this receipt of registration cancels the one delivered on $6^{\text {th }}$ November 1964. This law defines an association as "a convention by which two or more people permanently share their knowledge or activity in another goal than sharing profit". It is, however, accepted that the institutionalisation of applied linguistics, in France, started in 1958 with the creation of the "Centre de linguistique appliquée" in Besançon, followed by "Études de linguistique appliquée", a journal launched by Bernard Quemada (Candel 2011: 99). Later, "La revue français de linguistique appliquée" published its first issue in 1996. For a detailed analysis of these two journals, the reader is referred to Candel and Feuillet (2015).

\footnotetext{
${ }^{1}$ This section draws on an issue coordinated by Andrew Linn, Danielle Candel and Jacqueline Léon called "Linguistique appliquée et disciplinarisation" (Applied linguistics and disciplinarisation) published in Histoire Epistémologie Langage in 2011. To read the full issue: http://www.persee.fr/issue/hel_0750-8069_2011_num_33_1 (14/12/2017).

2 http://www.afla-asso.org/ (11/01/2018)

3 http://www.aila.info/en/ (11/01/2018)
} 
Figure 1: AFLA's declaration of administrative creation in 1964.

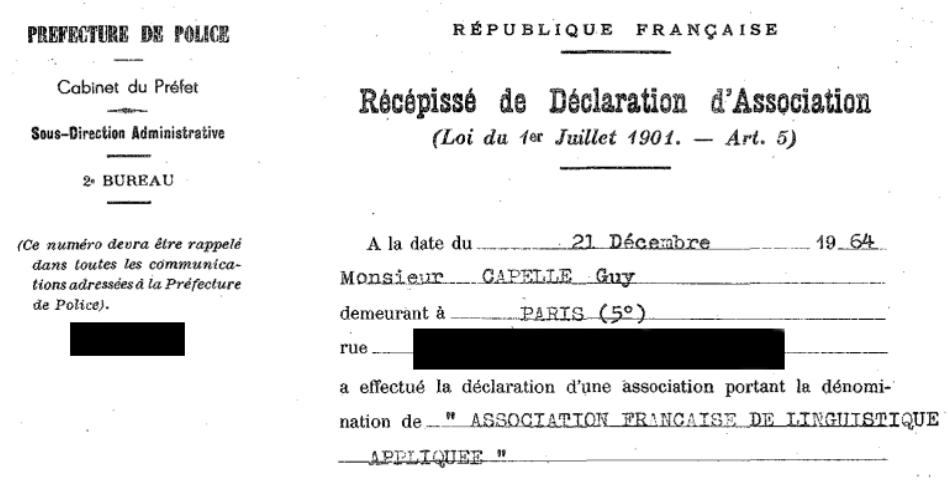

The institutionalisation of applied linguistics ( $A L)$ is a recent phenomenon even if linguists had confronted language theories and the teaching and learning of languages long before 1964. Linn et al. (2011: 2) recognize that, from the early beginning, Applied Linguistics included various domains such as the ones mentioned above as well as others such as automatic translation. This institutionalisation of the discipline at the time of its creation had two major and specific characteristics (Linn et al. 2011: 8):

1. An international scope: this aspect was completed with the creation of AILA;

2. A strong national anchorage: in France, it started with vocabulary studies and lexicology. Linn et al. (2011) suggest other contextualised needs in the USA and other Englishspeaking areas, and in Germany and Scandinavian areas.

Specifically in France, Carton (2015: 27-9) highlights three factors that explain the emergence of Applied Linguistics:

1) Substantial cultural changes during the 60 's leading to a desire for innovation.

2) The joint development of linguistics theories and communication technologies inducing intellectual emulation.

3) An institutional context favourable to change in French universities allowing an improved visibility and acknowledgment of language studies.

From the beginning, the statutes of AFLA mentioned that the association aims at "promoting and coordinating research in all the domains of applied linguistics and encouraging interdisciplinary and international cooperation in these domains" (article 1). All AFLA executive boards and presidents have tried to implement this objective in their policy. Table 1 shows some of the AFLA presidents since its creation. 
Table 1: AFLA presidents (years and names in bold are confirmed).

\begin{tabular}{l|l} 
Dates & Names \\
\hline $1962-?$ & Antoine Culioli \\
$?$ & Hélène Huot \\
$2000-2001$ & Isabelle Leglise \\
$?$ & Annie Delaveau \\
$2006-2012$ & Geoffrey Williams \\
$2012-2017$ & Jean-Paul Narcy-Combes \\
$2017-$ & Grégory Miras \\
today(2018) &
\end{tabular}

It is important to mention that a precise history of AFLA is hard to trace as it had to face serious political and human tensions leading, on the one hand, to the creation of the Association des chercheurs et enseignants didacticiens des langues étrangères (Acedle) in 1989 and, on the other, to the resignation of a number of the members of the executive board and of the organizing committee on $8^{\text {th }}$ December 2001. Candel and Feuillet (2015: 35-36) mention three historical steps for Applied Linguistics in France and AFLA:

1) 1958-1966: nine early crucial years for Applied Linguistics in terms of national and international institutionalisation.

2) 1990-1996: a warning and what came afterwards when during the 1993 AILA world congress in Amsterdam, AFLA was threatened with disaffiliation due to its lack of activity.

3) 2008-2012: a gradual resumption of activity within AFLA, first at a national level and then at international level when several members of AFLA met during the 2014 AILA world congress in Brisbane (Australia).

Two key elements have to be taken into account when it comes to understanding the role and the contextualised situation of applied linguistics at international and national levels. First of all, applied linguists should find solutions to real world problems (Brumfit 1977). At the time, social needs were related to contemporary international migrations in the $19^{\text {th }}$ century and then to the fall of colonial empires in the 1960s leading to high demand in foreign language learning (Linn et al. 2011: 9). Secondly, Applied Linguistics is constitutively pluri- and interdisciplinary, and thus is linked to related domains or disciplines such as pedagogy and sociology.

According to Candel (2011) who examined the term "applied linguistics" in dictionaries and in seminal texts:

The scope of applied linguistics appears quite rich, but it is also perceived as being composite, and this has led to negative judgments, concerning the denomination as well as the designated area. Finally, the definitions have reached a measure of stability, the applied side continues to outweigh the theoretical one, and the discipline continues to evolve. (Candel 2011: 113) 
For Candel, this highlights the vitality of applied linguistics. Despite that fact, AFLA and its members have experienced a number of challenges; the association is currently undergoing a promising process of revitalisation and has an important role to play in a newly redefined field of applied linguistics in contemporary French research.

\section{AFLA's renewed conception of $A L^{4}$}

As mentioned by Danielle Candel above, the term appliquée (applied) in linguistique appliquée (Applied Linguistics), in France, may hold negative judgments that partly explain why the field is not as strong as it is in other countries and in scientific literature published in English. The second contextualized element, that has to be taken into consideration, is the French specificity of the links between applied linguistics and "didactique des languescultures" (teaching and learning of languages and cultures). Chevalier and Encrevé (2006) summarize these tensions:

The notion of "linguistique appliquée" was soon perceived as pejorative in a country where only fundamental research is promoted, no matter its quality, and which is suspicious of what comes from the field. The notion was related to prestigious disciplines [...]; but teachers felt ignored. (Chevalier and Encrevé 2006: 95-96)

In France, Applied Linguistics, seen as a network of researchers, has had to face a shift with the old but ongoing debate over the claim of disciplinary specificity, with "Didactique des langues-(cultures)" relying on a diachronic perspective and a synchronic theorization which are more than a simple "application" suggested by the term "applied" linguistics (Chiss 2009: 129). This paper will not further develop the contextual links between Fundamental Linguistics, Applied Linguistics and Didactique des langues-cultures in France; the reader is referred to other sources such as Chiss (2009).

Following the words of Michael Halliday, in Léon (2011: 79), who considers "Applied Linguistics as an evolving theme", Condamines and Narcy-Combes (2015: 1) suggest that the concept of Applied Linguistics could be revisited in order to alleviate historical tensions. One of the key points is terminological, implying that instead of considering "Applied" Linguistics, the focus should be on the notions of située (situated) and/or impliquée (involved/engaged/committed). In their view, and as an extension of what Brumfit (1977) called real world problems, situated science implies a perspective in which research is not simply applied to a project but in which it is part of the project where the two are interconnected and modify each other so that the project may go forward. Bonneuil and Joly (2013: 19) theorized this point concerning the interconnected relations between science and society. This point leads to the fact that science is situated by socio-political constraints (Callon \& Latour 1991; among others) and a contemporary episteme (cf. uncertainty and complexity according to Narcy-Combes, 2010). This does not imply that research is a completely relative process, as Klein (2008) mentions it in the field of physics:

The sociology of science is right to insist on the importance of context in the way it builds itself. Yet, should it be concluded that scientific results are radically relativistic. Certainly not. (Klein 2008: 75)

\footnotetext{
${ }^{4}$ This section draws on a paper written by Anne Condamines and Jean-Paul Narcy-Combes entitled "La linguistique appliquée comme science située" (Applied linguistics as a situated science") published in Cultures de recherche en linguistique appliquée in 2015. To read the full paper: https://hal.archives-ouvertes.fr/hal-01286390 (14/12/2017).
} 
According to Condamines and Narcy-Combes (2015: 2), "an idealistic scientific pathway would start from a distanciation leading to a reflexion/description linked to one or several theories and allowing authentic actions". Action can lead to "engagement" which is a step further than Situated Linguistics and needs to question researchers as citizens. Distanciation, research methodologies and epistemological responsibility provide checks and balances to ensure objectivity. Objectivity is not the opposite of subjectivity, nor is it neutral when conducting research. It depends on how the researcher considers himself or herself "committed", in terms of ethics, individual posture and deontology (Corijn, 2006). A balance obviously has to be found between commitment and scientific distanciation, but it would be difficult to say there is no hidden political agenda in research on education, for example. Researchers are becoming increasingly aware of their potential political involvement, which may be a good sign.

Following on from this, the two authors suggest that Linguistics is a situated science, and thus question the relevance of the opposition "Applied Linguistics vs. Linguistics" (Condamines \& Narcy-Combes 2015: 13) and maybe even "vs. Didactique des languescultures".

\section{Fields of interest}

The different domains of Applied Linguistics covered by AFLA members are highly varied: language acquisition, contrastive analysis, speech analysis, L1 and Lx teaching and learning, child language, professional language, minority and regional languages, lexicology, language policy, language disorders, translation, terminology, automated language-processing, corpus-based approaches, digital technologies, etc.

Considering the landscape of language studies in France, AFLA has developed strong and deep links with partner associations in order to take into account the diversity of languages, teacher professional networks and other transdisciplinary complementary domains (see Table 2). The intention is for other partner associations to join during our next annual meeting in 2018, fulfilling our goal to better represent all the fields of Applied Linguistics. Sign languages deserve a mention with Trait d'Union or the Association Française des Interprètes et Traducteurs en Langue des Signes (AFILS), along with research into English learning and teaching with Association pour la Recherche en Didactique de l'Anglais et en Acquisition (ARDAA) or on language studies with Association des Sciences du Langage (ASL) and biligualism with Association pour le Développement de l'Enseignement Bi/plurilingue (ADEB).

Table 2: Official Partner associations in 2017 


\begin{tabular}{|c|c|c|}
\hline Acronym & Full name & Keywords \\
\hline ACEDLE & $\begin{array}{l}\text { Association des Chercheurs et } \\
\text { Enseignants Didacticiens des } \\
\text { Langues Étrangères }\end{array}$ & $\begin{array}{l}\text { Second-language } \\
\text { teaching/learning }\end{array}$ \\
\hline APLIUT & $\begin{array}{l}\text { Association des Professeurs de } \\
\text { Langues des Instituts } \\
\text { Universitaires de Technologie }\end{array}$ & $\begin{array}{l}\text { Second-language } \\
\text { teaching/learning; } \\
\text { University Institutes } \\
\text { of Technology }\end{array}$ \\
\hline$A P L V$ & $\begin{array}{l}\text { Association des Professeurs de } \\
\text { Langues Vivantes }\end{array}$ & $\begin{array}{l}\text { Primary/secondary } \\
\text { school language } \\
\text { teachers }\end{array}$ \\
\hline ASDIFLE & $\begin{array}{l}\text { Association de Didactique du } \\
\text { Français Langue Étrangère }\end{array}$ & $\begin{array}{l}\text { French as a foreign } \\
\text { language } \\
\text { teaching/learning }\end{array}$ \\
\hline GERALS & $\begin{array}{l}\text { Groupe d'Étude et de } \\
\text { Recherche en Allemand de } \\
\text { spécialité }\end{array}$ & $\begin{array}{l}\text { German for specific } \\
\text { purposes research }\end{array}$ \\
\hline GERAS & $\begin{array}{l}\text { Groupe d'Étude et de } \\
\text { Recherche en Anglais de } \\
\text { spécialité }\end{array}$ & $\begin{array}{l}\text { English for specific } \\
\text { purposes research }\end{array}$ \\
\hline GERES & $\begin{array}{l}\text { Groupe d'Étude et de } \\
\text { Recherche en Espagnol de } \\
\text { spécialité }\end{array}$ & $\begin{array}{l}\text { Spanish for specific } \\
\text { purposes research }\end{array}$ \\
\hline RANACLES & $\begin{array}{l}\text { Rassemblement National des } \\
\text { Centres de Langues de } \\
\text { l'Enseignement Supérieur }\end{array}$ & $\begin{array}{l}\text { University language } \\
\text { centres }\end{array}$ \\
\hline SFT & $\begin{array}{l}\text { Société Française de } \\
\text { Terminologie }\end{array}$ & Terminology \\
\hline SHESL & $\begin{array}{l}\text { Société d'Histoire et } \\
\text { d'Épistémologie des Sciences } \\
\text { du Langage }\end{array}$ & $\begin{array}{l}\text { History and } \\
\text { epistemology in } \\
\text { language studies }\end{array}$ \\
\hline
\end{tabular}

The upcoming years will be devoted to defining a small number of themes that will reorganize the association not in terms of subdomains but in terms of transdisciplinary research responding to social needs and contemporary challenges.

\section{Activities}

AFLA members have been rethinking the notion of Applied Linguistics in many ways beyond our borders, including: 
- Participating in AILA conferences and EBIC meetings:

2014 AILA world congress in Brisbane (Australia) and 2017 AILA world congress in Rio (Brazil).

- Publishing papers and coordinating scientific issues, recent examples being:

Miras, G. (ed., 2017). Emergentism. RDLC - Les cahiers de l'Acedle. 14-1. (Available online https://rdlc.revues.org/1082).

Carton, F., Narcy-Combes, J.-P., Narcy-Combes, M.-F., Toffoli, D. (2016, eds.). Cultures de recherche en linguistique appliquée ${ }^{5}$. Paris: Riveneuve éditions.

- Organizing national conferences:

Table 3 shows a few historical examples of congresses for which AFLA has been involved.

Table 3: A few historical examples of conferences and other events.

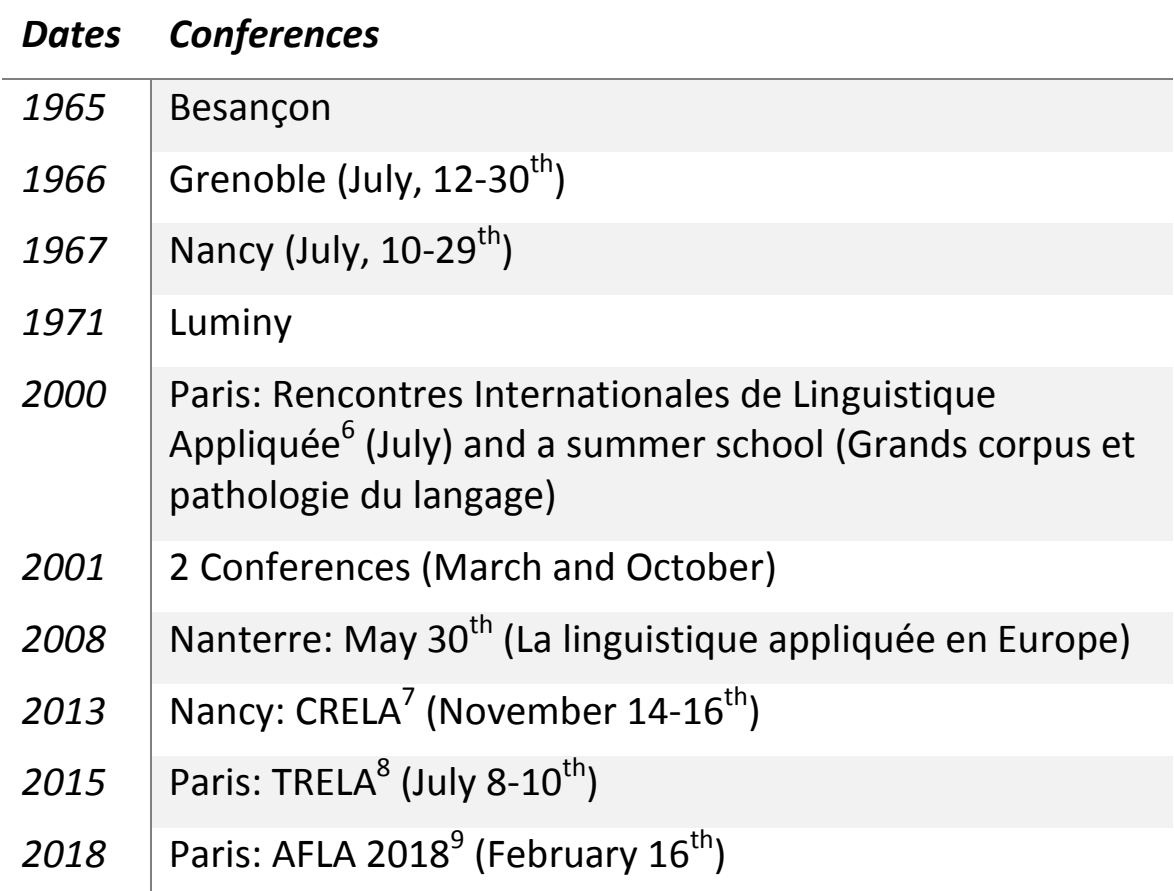

The last two conferences in 2013 and 2015 focused on Research Cultures in Applied Linguistics (CRELA, Nancy) and Areas of Research in Applied Linguistics (TRELA, Paris). Both considered that Applied Linguistics in the $21^{\text {st }}$ century is a rich and varied discipline, with many sub-domains. Each of these has its own research tradition, often associated with the particular countries in which it developed: language acquisition/learning, bi- and multi-

\footnotetext{
${ }^{5}$ http://www.riveneuve-editions.com/catalogue-2/actes-academiques/cultures-de-recherche-en-linguistique-appliquee/ $(27 / 12 / 2017)$

${ }^{6}$ https://www.cairn.info/revue-francaise-de-linguistique-appliquee-2001-1-page-4.htm (28/12/2017).

7 http://www.atilf.fr/crela2013/ (28/12/2017).

8 http://trela.clillac-arp.univ-paris-diderot.fr/ (28/12/2017).

9 http://www.afla-asso.org/afla2018/ (28/12/2017).
} 
lingualism, didactics, lexicography, corpus linguistics, terminology, translation studies, computational linguistics, variation, etc. However, these disciplines often share similar research fields and methodologies. Transdisciplinarity and multidisciplinarity are trademarks of the $21^{\text {st }}$ century, as can be seen in the emergence of so many multi- or transdisciplinary fields, including examples which combine "humanities" and "pure sciences". Applied Linguistics, because of the variety of fields which it is involved in, has followed the inexorable development of this process of hybridization. Furthermore, the practice of Applied Linguistics has come to involve not only the application of theoretical knowledge, but also the emergence of new fields of investigation, which then feed back into current debates within the language studies. The aim of the TRELA 2015 international conference that followed the CRELA conference in Nancy 2013, which questioned the notion of Linguistique Appliquée in France nowadays, was to allow researchers and other practitioners in the different fields of Applied Linguistics to discuss and debate issues relating to common areas of research, pooling ideas on these topics from a multidisciplinary or transdisciplinary perspective.

AFLA has a number of upcoming events in 2018, 2019 and 2023. In 2018, our annual meeting will focus on how language studies can respond to social needs. Participants will talk about their research and its links to social needs through public or private institutions such as practicing as an otolaryngologist, applying linguistics in businesses, doing forensic linguistics, building a gender-neutral French language and questioning the role of the linguist in minority languages such as French Sign Language. The aim will be to foster a dynamic trend regarding the possible continuum of engagement/commitment of researchers in social needs (or at least to make them more visible). This first step will pave the way for our 2019 annual event combined with the AILA EBIC meeting, followed by the 2023 AILA world congress in Lyon (France) entitled "Diversity and social cohesion in a globalized world: Moving toward more engaged language studies".

- $\quad$ Leading AILA Research Networks (ReN):

2013-2016 (convenor: Jean-Paul Narcy-Combes): "Sociocultural theory and emergentism". The scope was to question how current trends in SLA research are largely concerned with the socio-cultural contexts of language acquisition/learning and have therefore rediscovered the importance of Vygtskyan thinking. Even if we agree on the major aspects of this approach, there is still a theoretical gap with regard to the overarching concept of learning which recent research on emergentist views of learning processes might help to fill. The work of the ReN aims at modelling the mental and developmental processes of second language acquisition/learning within social interaction and at conducting empirical research in this field. Some of the participants are engaged in a common research project based on a computer-enhanced transnational, multilingual and multicultural learning environment. The exchange between this project and the larger circle of ReN members is promising for both sides.

2018-2020 (convenor: Shona Whyte): “Crosslinguistic perspectives on the terminology of language teaching and learning research in French and English". The scope of the ReN is to analyse how the crosslinguistic L2 studies terminology network seeks to contribute to collaboration across French-speaking and English-speaking scholarly communities by offering a forum for participants to review, clarify, and update terms in second language 
acquisition, second and foreign language teaching, educational linguistics, and language education across the two languages and cultures. It may be possible to extend the project to additional languages (German, Italian, Spanish) if progress is significant and a second term for the network seems fruitful.

\section{Conclusion}

This brief history of "Applied Linguistics" and "Linguistique appliquée" in France should not be taken as an attempt to dwell on the past but should help us to look forward to the future of our field. As a (non-)conclusion, Stegu (2011) may be right when he says that:

Applied Linguistics is nothing of the above [an autonomous (meta)discipline or a more-or-less autonomous gathering of (sub)disciplines] or it is all of the above: it is nothing but a summary of all that was said or written about it and of all that will be said or written. (Stegu 2011: 138)

However, situated science such as Applied Linguistics is a way for researchers to take part in the knowledge-based society. This role is even more important given the challenges our societies and our world are facing in this beginning of the $21^{\text {st }}$ century.

\section{References}

Bonneuil, Christophe \& Pierre-Benoit Joly. 2013. Sciences, techniques et société. Paris, La dispute.

Brumfit, Christopher. 1997. How applied linguistics is the same as any other science. International Journal of Applied Linguistics 7(1). 86-94.

Callon, Michel \& Bruno Latour. 1991. La science telle qu'elle se fait. Paris : La Découverte.

Candel, Danielle \& Jacqueline Feuillet. 2015. Les "Linguistique appliquée ", ou relire les Études de linguistique appliquée (ELA) et la Revue française de linguistique appliquée (RFLA) (1962-2012). In Francis Carton, Jean-Paul Narcy-Combes, Marie-Françoise Narcy-Combes \& Denyze Toffoli (eds.), Cultures de recherche en linguistique appliquée. Paris: Riveneuve éditions. 33-52.

Candel, Danielle. 2011. "Linguistique appliquée » : Parcours définitoires et lexicographiques. Histoire, Epistémologie, Langage 33 (1). 99-115.

Carton, Fernand. 2015. Quand naissait I'AFLA: témoignage. In Francis Carton, Jean-Paul Narcy-Combes, Marie-Françoise Narcy-Combes \& Denyze Toffoli (eds.), Cultures de recherche en linguistique appliquée. Paris: Riveneuve éditions. 27-32.

Chevalier, Jean-Claude \& Pierre Encrevé. 2006. Combats pour la linguistique, de Martinet à Kristeva. Lyon: ENS Éditions.

Chiss, Jean-Louis 2009. Sciences du langage et didactique des langues: une relation privilégiée. Synergies Roumanie $\mathrm{N}^{\circ} 4$. 127-137.

Condamines, Anne \& Jean-Paul Narcy-Combes. 2015. La linguistique appliquée comme science située. In Francis Carton, Jean-Paul Narcy-Combes, Marie-Françoise Narcy-Combes \& 
Denyze Toffoli (eds.), Cultures de recherche en linguistique appliquée. Paris: Riveneuve éditions. 209-229.

Corijn, Eric. 2006. Éléments d'un projet pour Ixelles. Une contribution citoyenne. Bruxelles : Parcours Citoyen.

Klein, Etienne. 2008. Allons-nous liquider la science ? Galilée et les indiens. Paris : Flammarion, Champs sciences.

Léon, Jacqueline. 2011. La linguistique appliquée dans la tradition britannique. Histoire, Épistémologie, Langage 33 (1). 69-82.

Linn, Andrew, Danielle Candel \& Jacqueline Léon. 2011. Présentation: Linguistique appliquée et disciplinarisation. Histoire, Epistémologie, Langage 33 (1). 7-14.

Narcy-Combes, Jean-Paul. 2010. L'illusion ontologique en didactique des langues. Le français dans le monde, Recherches et applications $n^{\circ} 48$. Paris : Clé International. 111-122.

Stegu, Martin. 2011. La linguistique appliquée : discipline ou regroupement de disciplines indépendantes ? Histoire, Epistémologie, Langage 33 (1). 129-139.

Contact information

Website: http://www.afla-asso.org

E-mail address: gregory.miras@univ-rouen.fr

Social networks:

https://twitter.com/AFLApplique

https://www.facebook.com/aflapplique/ 